\title{
Key Dimensions of Effective Leadership for Change: A Focus on Township and Rural Schools in South Africa
}

\author{
Thandi Ngcobo and Leon Paul Tikly
}

\begin{abstract}
The article identifies key dimensions of effective leadership for change in historically disadvantaged, township and rural schools in South Africa. It is based on original case study research in 13 schools in Kwa-Zulu Natal. Although the sample included mainly township and rural primary and secondary schools it also included a smaller sample of historically advantaged formerly White, Indian and 'Coloured' schools. All schools were selected on the basis of high academic achievement and success in implementing change. Effective leadership styles were found to be contingent on context. Rather than providing a fixed set of characteristics the dimensions provide a framework against which the nature of effective leadership in the sample schools is analysed and compared. It is argued that although many aspects of effective leadership are similar to those reported in the wider international literature, they assume a specific form and emphasis related to contexts of disadvantage in South Africa.
\end{abstract}

Keywords: change, effective leadership, rural schools, South Africa, township schools

\section{Introduction}

The post-1994 South African government has invested great hope in education as a basis for broader societal transformation (see Harley et al., 2000; Harber, 2001; Taylor et al., 2003; Chisholm, 2004). The government's investment in education has tripled since the end of apartheid. ${ }^{1}$ At 6.6 per cent of the country's GDP and 17.7 per cent of total government spending, the country's education spending rate is high by international standards (SAInfo, 2007). The government has instigated wide-ranging initiatives to transform education from its apartheid past including improved access to education; efforts to reinstate a culture of teaching and learning in schools; a new, more equitable basis for school finance including an index of need and efforts to rationalize and redeploy staff; and, wide-ranging curriculum reform including the introduction of outcomes based education. However, despite years of reform effort, South Africa continues to lag behind in international comparisons and has failed to significantly raise the performance of historically disadvantaged learners (Taylor et al., 2003; Soudien, 2007). For some commentators the problem lies in the legacy of apartheid including deeply entrenched class and race relations (Soudien, 2004, 2007; Chisholm 2004). For others it lies in the contradictory nature of post-apartheid policy torn as it is between social democratic goals of redistribution on the one hand and neo-liberal tendencies on the other (Harber, 2001; Tikly, 2003). 
In his own typically candid assessment, Jansen (2001, 2002, 2005) has identified a lack of the 'essentials' by which he means suitably qualified and motivated teachers, appropriate textbooks (and other learning materials) and time on task.

A factor that has consistently been identified in the international literature over the last quarter century at least as being critical for managing change and raising the achievement of learners is that of effective leadership. This is true in both high (see for example, Weber, 1971; Edmonds, 1979; Purkey and Smith, 1983; Mortimore, Sammons, Stoll, Lewis, \& Ecob, 1988; Sammons, Hillman, \& Mortimore, 1995 and Fink, 2000) and low (see Lockheed and Levin, 1993; Heneveld, 1994; Heneveld and Craig, 1996; Velez et al., 1993) income settings. Perhaps surprisingly, this has received only limited attention to date from researchers interested in South African education (see Christie, 2001; Calitz, 2002; Coleman, 2003, Lumby, 2003; Prew, 2007) and there is a shortage of evidence about what constitutes effective leadership particularly in the most disadvantaged and difficult delivery contexts. The aim of this article is to contribute to an understanding of effective leadership through a focus on historically disadvantaged township and rural schools in South Africa during times of turbulent change. The article draws on the results of original case study research in 13 schools in Kwa-Zulu Natal province.

In designing our study we have focused on disadvantaged schools that are doing relatively well in raising achievement. It should be pointed out that while we agree with the wider evidence concerning the central role of effective leadership in successful schools, we are not suggesting that the leadership is solely responsible for this success. Postulating such a causal relationship would be to over-simplify a complex situation and it is more likely that the reasons behind the successes of the schools are in fact multi-dimensional. We are nonetheless interested in the role that leaders play in these contexts and how leadership interacts with wider contextual and other factors to facilitate positive change. In drawing attention to leadership practices in more successful township and rural schools we also hope to balance the generally negative view of such schools and to point to some of the successes of leaders, educators and school communities. We also hope to provide examples of practices that school leaders and policymakers engaged in similarly challenging contexts may find relevant for informing their work.

The article will begin with an overview of our theoretical framework and in particular what we understand by 'effective leadership' in the South African context and our methodology. The article will then provide an overview of the macro and micro contexts facing the case study schools as a basis for setting out the key characteristics for effective leadership in subsequent sections. The characteristics will be illustrated with a selection of vignettes and quotes from respondents in the case study schools. In conclusion the article will summarize our main findings and identify areas for further research. The main argument advanced in the article is that while effective leadership 
is to a large extent contingent on context it is possible to identify key dimensions of leadership that are relevant to township and rural schools.

\section{Understanding Effective Leadership in the South African Context}

The aim of this section is to locate our own study within the international literature on effective leadership. The concept of effective leadership is often associated with the school effectiveness tradition. Within this tradition, 'effectiveness' has often been defined in relation to a quantifiable measure of outcomes such as exam results. Such an approach has been criticized for not taking sufficient account of other potential outcomes that are reflected in education policy including HIV/AIDS awareness, the skills and attitudes required to combat HIV/AIDS, to alleviate poverty, to support sustainable development, to create 'good citizenship' or a more equitable and socially just society (Morley and Rasaool, 1999). While we acknowledge these critiques it is also the case that these outcomes are hard to assess and in the absence of relevant data we used improvement in academic achievement along with the perceptions of the ability of schools to manage complex change as key criteria for identifying 'effective' schools as a starting point. Having made our initial selection using these standard criteria, however, we also chose to problematize the idea of effective leadership as a research theme in itself. Our results reveal that for many respondents while traditional measures of academic achievement were important, so were a range of other outcomes.

This relates to a second major criticism of the concept of effective leadership in that there is a danger that criteria that are considered to be effective in certain contexts (usually western industrialized contexts) are then taken to be universal. Existing studies have identified a range of factors associated with effective leadership (Scheerens and Bosker, 1997; Leithwood et al., 1999; Day et al., 2000; Fullan, 2003; Russell, 2003; Sergiovanni, 2005). Recent studies of school quality in South and East Africa have added to our understanding of these factors (Yu, 2007). These studies have been important for shaping our own initial conceptions. Mullford (2003), however, has argued that whilst there may be universal characteristics in relation to what constitutes effective leadership and indeed effective education, these need to be questioned rather than assumed. The need to develop a contextualized understanding of leadership practices in Africa and elsewhere is shared by other authors (Riley, 2000; Horner, 2003; Riley and Macbeath, 2003; Crossley et al., 2005; Oduro, 2006). Understandings need to be seen, interpreted and possibly amended in the light of local values, perceptions and realities and there is a need to engage with local goals of education and leadership 'which relate to the specific needs of children who live in distinct communities and which may vary from school to school' (Townsend, 1994: 105). Recognizing variation in local priorities and needs lends support to the view that effective leadership styles are contingent on context, i.e. '... there is no one package for school leadership: no one model to be learned and applied, regardless of culture and context'. We aim to provide evidence to inform this debate through 
providing a contextualized understanding of effective leadership in largely contrasting locations in South Africa.

The existence of a degree of flexibility about what constitutes effective leadership is widely recognized in times of complex change (Fullan, 2003). It also draws attention to the contested nature of the term as it is caught between various interpretations on the part of different stakeholders with differing interests in the outcomes of the leadership process. Such a view is particularly important in the South African context given the legacy of apartheid education policy and of the struggles to end authoritarian and often dehumanizing forms of leadership which was premised on the creation of separate education systems with separate values, purposes and styles of leadership. For these reasons, rather than seeking to promote one overarching model of 'effective leadership' we more modestly identify a set of dimensions against which the specific nature of effective leadership in different contexts can be evaluated and to set these within a larger context of the on-going transformation of the education system from highly unequal and racially based systems under apartheid past to a non-racial, democratic and more equitable one.

For the reasons mentioned above the team were keen to adopt a grounded theory approach and to allow as far as possible the various dimensions of effective leadership to emerge from the data itself (Strauss and Corbin, 1990). Strauss (1970) acknowledges that grounded theory can be used to extend existing theory. In this respect we did not approach the research with a completely blank slate. We were also guided by ideas from the international literature and it is important to make explicit what these were. The first of these concerns the evidence concerning the often distributed nature of effective leadership in many contexts, i.e. that 'leadership in schools and colleges is not confined to head teachers and may be assumed by or dispersed to others including deputy heads, team leaders, curriculum leaders and class teachers' (Coleman, 1994: 61). Furthermore, leadership may be exercised by those with formal positions of authority and less formally by individuals at any level or position within the school (Fink, 2000; Ngcobo, 2005) or surrounding community that have specific expertise (for example technical or cultural expertise) or hold different kinds of power (for example, a member of the governing body who enjoys high regard within the community).

Second, it is often argued that effective leadership for change relates to transformational capacity (Day et al., 2000; Latchem and Hanna, 2001; Coleman, 2003) and to the ability of leaders to motivate their fellow professionals by transforming 'self interest into the interest of the group through concern for a broader goal' (Rosener, 1990: 20, see also, Burns, 1978; Sergiovanni, 2005). However, while the evidence concerning the links between transformational leadership styles and effective leadership is strong in high income, western contexts there is more limited evidence concerning the relevance of transformational styles for effective leadership in historically disadvantaged and culturally diverse settings such as those represented 
by township and rural schools (Boardman, 2001; Parshiardis, 2001; Singh and Lokotsch, 2004). Understanding the contingency of transformational and transactional styles and the relationship between them therefore became a central concern for us.

Much of the existing literature is framed by formal structural assumptions about the nature of leadership (Calitz, 2002; Coleman, 2003). More recent research, however, has highlighted the importance of informal inputs for school leadership effectiveness including the role of sometimes conflicting values and the cultural dimension (Leithwood et al., 1999; Day et al., 2000; Boardman, 2001). This relates to our view of the historically contested nature of leadership in the South African context. In line with this, a guiding hypothesis in this study was that leadership effectiveness depends to a significant degree on the extent to which 'leadership' is able to achieve congruence between differing stakeholder values. This lays emphasis on the role of leaders in seeking to understand, negotiate and influence stakeholder values in relation to changing internal and external needs.

The values that leaders of township and rural schools must engage with in South Africa are unique and need to be understood at various levels. Leaders must learn to manage across the boundaries and to deal with the new values emanating from national and provincial policy that may or may not clash with the values of teachers, parents and pupils. For example, the introduction of outcomes based education (OBE) and the abolition of corporal punishment and measures to ensure gender equity and redress in national policy need to be implemented against a backdrop of the quite traditional values that continue to be held by some teachers and parents as a consequence of their own past experiences and the legacy of apartheid education policy. The question of values in educational leadership is also related to differing political traditions and realities in the townships. During the transformation period schools became virtual battlegrounds and sites of struggle over these values which included differing conceptions about what education was for. Political structures in the township continue to exert an influence over the values of schools, as will be discussed below.

Conflicting political traditions in the townships are linked in complex and fluid ways to ethnic identities and values. Leaders also need to be aware of the influence of cultural norms and values in the community within which a school is situated. However, rather than see these as relatively fixed over time as some commentators do we see identities and values as in a constant state of flux. Thus, for example, whereas some authors (Foskett and Lumby, 2003) have suggested that traditional African culture is premised on respect for elders rather than on so-called democratic principles and on quite conservative views about gender roles we found both of these assumptions to be problematic in relation to our case study schools. Rather, we prefer a view of culture as being more hybrid than traditional management theory makes allowances for, prone to change and contestation about how it ought to be interpreted 
between young and old, men and women, rich and poor. The 'reality' that we encountered was one in which 'traditional' values increasingly compete with outside influences. In South Africa this is compounded by migratory labour which finds rural values continually enmeshing with the urban. Rather than deal with a uniform set of values, this means leaders must deal with sometimes quite differing sub-cultures and values held by different groups within the local community and the school that constitute something of a 'moving target'.

Such a view also serves to underline the central role of human relationships in leadership and change management. This is because managing change often requires helping people to overcome barriers to change and this requires emotional intelligence and the fostering of meaningful relationships (Fullan, 2003). The emphasis on values also draws attention to the processes by which leaders get involved in order to influence values as much as the individual attributes possessed by leaders (MacBeath et al., 1998; Day et al., 2000; Foskett and Lumby, 2003; Fullan, 2003). Day et al.'s (2000) model was particularly influential on the team. In this model of effective leadership leaders align their values and vision with that of others; they demonstrate integrity and 'walk the talk'; they are suitably responsive to outside change; and, they promote the continuing professional development of staff (including themselves) through teamwork, collaborative management, the provision of continuing professional development and critical reflection.

Taken together the above considerations formed a conceptual backdrop against which we conducted the research. To some extent our findings reaffirmed those of other studies. In other respects, however our findings extended and even challenged existing views.

\section{The Study}

Consistent with our concern to investigate the underlying processes of leadership and to embed our understanding within an appreciation of the different contexts, we adopted a qualitative case study methodology. As suggested by Yin (2003: 13), a case study is an empirical inquiry that investigates a contemporary phenomenon within its real-life context, 'especially when the boundaries between phenomenon and context are not clearly evident'. A virtue of a case study approach from the point of view of the study is that it allows for multi-perspective analyses. 'This means that the researcher considers not just the voice and perspective of the actors, but also of the relevant groups of actors and the interaction between them' (Tellis, 1997).

Schools were purposively chosen using academic performance and ability to manage change as key criteria although other factors were taken into account. Good performance in national matriculation examinations formed the basis for the selection of secondary schools. Schools identified using this criterion were then subjected to perceptions by regional officials (subject advisors) regarding the schools' ability to manage change in general and to implement the new OBE in particular. 
These perceptions were particularly important in selecting primary schools for the sample since the South African education system does not provide for nationally determined external assessments at this level. Claims by the subject advisors were that those schools that were coping with the implementation of this complex curriculum were also coping well with the management of other changes. The view was that the subject advisors' experiences with the schools brought an element of objectivity in the selection of schools at this level.

Convenience sampling was also used in selecting schools. For example, schools were selected in districts where the team had well established contacts who could report on the performance of the schools in relation to the selection criteria. The bias towards secondary schools reflects the greater accessibility and reliability of learner outcome data at the secondary level while the bias towards urban schools reflected the greater ease with which these schools could be accessed by the team. The bias was not inconsistent with project aims however, insofar as there is some evidence that township schools as a whole under-perform compared to their rural counterparts, and that this is related to the historical legacy of the breakdown of teaching and learning in townships during the last years of apartheid and with the subsequent legacy of politically motivated violence (Christie, 1997).

In focusing on township and rural schools serving the African community we wanted to broadly reflect the demographic realities of the province in that most children attend these kinds of schools. We also hoped to address a major gap in the literature. We were, however, also acutely aware that township and rural schools operate within a larger unified system and so the sample also included one former Indian and one former Coloured school along with two formerly white schools all of which are now desegregated. However, these schools acted as a point of comparison with the historically African township and rural schools rather than as a key focus for the research itself. ${ }^{2}$

Each case study school was visited once over a period of two days. 3 All the principals and deputy principals in the sample schools were individually interviewed along with two heads of department (HODs) in each school. The sample of HODs was biased towards those who had been teaching at the school for a longer period of time and had therefore witnessed more changes than members of staff. Data from teachers, parents and pupils were gathered in focus groups of five-six participants in each group. The pupil focus groups comprised learners perceived to be 'influential' members of the schools' student bodies. In secondary schools this meant Learner Representative Councils (LRCS) membership while it included class prefects in primary schools. Learners from different levels of schooling/study were chosen to get a spread of ages/abilities. The sample of teachers was more opportunistic in each school although as was the case with the other categories of respondents, a gender balance was purposefully sought. 
Table 1. Sample composition

\begin{tabular}{lllll}
\hline & Rural schools & Township schools & Suburban schools & Total \\
& 03 & 06 & 04 & 13 \\
\cline { 2 - 5 } African & Historically White & Historically Indian & Historically Coloured & Total \\
09 & 02 & 01 & 01 & 13 \\
\hline & Primary schools & Secondary schools & Combined schools & Total \\
& 04 & 07 & 02 & 13 \\
\hline
\end{tabular}

Questions covered in the interviews/ focus groups were concerned with the respondents' understanding and perceptions of the context of the school; the role of leaders in the school community including their own role; recent changes that leaders have had to deal with; the strategies that leaders used to deal with changes; and, perceptions of the dimensions of effective leadership. The semi- structured format allowed for prompts to be used to probe issues more deeply where this was felt necessary and to take account of and to pursue themes and issues raised by the respondents themselves. In addition to the interviews, contextual data relating to each school was also gathered. This included basic information statistics including numbers of learners, class sizes, teacher-pupils ratios, etc.; photographs of the schools and surrounding area; documents such as the schools' management structures and policies; and unstructured observations of the schools' culture and climate. Triangulation between data sources was an important way of ensuring the trustworthiness of findings. ${ }^{1}$

As mentioned, data analysis was informed by a grounded theory approach. 5 That is to say that analysis was conducted through a process in which findings were 'inductively generated from robust data patterns' (Haig, 2001: 2). This meant focusing on identifying what the participants valued and felt was important and for which they were so committed that they would allocate additional effort and time in each of the sample schools. This involved the:

- location of patterns and themes;

- checking of themes against observed actions; and

- articulation of assumptions viewed as underlying leadership in these schools. (Strauss and Corbin, 1990)

The results of the thematic analysis are presented below. They are preceded however with an overview of the contexts of leadership and change across the case study schools. 


\section{The Contexts of Change in the Case Study Schools}

This section reports on the macro context (national policy initiatives) and provides a summary of the various micro (institutional and local) contexts of change. The aim is to provide a necessary background for considering effective leadership in the next section. A more detailed account of these contexts is provided in Tikly, Ngcobo and Moorosi (2005) and so only the key issues will be addressed here. Turning first to the macro picture, some indication of the broader policy environment affecting schools has been given above. Among the large number of initiatives and changes that the schools in our sample typically had to deal with during the course of the study were the following:

- The devolution of enrolment responsibility to schools within the terms of the South African Schools Act (1996).

- The implementation of OBE.

- The rationalization and redeployment of staff.

- The abolition of corporal punishment.

- The introduction of ICTs into schools.

- The introduction of the Integrated Quality Measurement System (IQMS).

- In the case of the historically advantaged school, the admittance of increasing numbers of Black learners.

Together these changes represent a turbulent change environment (Fullan, 2003). Neither have the above changes had the desired effect at the desired rate (Jansen, 2001). They have not, for example, brought back the so-called 'culture of learning and teaching' in township and rural schools (Department of Education, 1996; Christie, 2001). Rather, they have contributed to what Welton (2001) has described as innovation overload.

Turning now to the micro context of change, there was considerable variation in the quality of education on offer in the case study schools. Space does not allow for a comprehensive account although the situation in many township and rural schools has been described elsewhere (Christie, 2001; Jansen, 2001). There was considerable variation in the qualifications of the teaching staff particularly between the historically advantaged and disadvantaged schools in the sample. Many of the township and rural schools had a large significant number of under-qualified staff. Principals in these schools also had to deal with the legacy of the breakdown of teaching and learning that took place from the mid 1970s to the early 1990 and continued to result in sometimes poor teacher and pupil attendance and punctuality. Stark contrasts were also evident in the provision of materials and buildings. The historically White schools in the sample were generally well endowed with the learning materials and equipment and benefited from excellent sports facilities.

Although, like the historically advantaged schools, some of the township and rural schools had been successful in mobilizing additional resources to purchase 
equipment (including science and ICT equipment) and learning materials the situation was uneven. Many of the township and rural schools continued to suffer from a sometimes acute shortage of textbooks and other learning materials. Similarly, although many of the successful principals had invested a lot of time and resource in trying to improve the environment of the school, many of the school buildings and grounds, particularly in the townships were dilapidated and in need of repair with holes in the ceilings and wall. There was a lack of recreational and sports facilities and the sanitary facilities on offer were often in a poor state and barely adequate to meet demand. Furniture and equipment such as photocopiers were often broken or vandalized. Many of the schools were overcrowded with numbers well in excess of the recommended learner-educator ratios. Given that this was the situation in many of the relatively successful township and rural schools one can only imagine what the situation might have been like elsewhere. Summing up the situation when he first took up his post one of the principals of a township secondary school provided the following poignant description of what he had found:

There were no fences; no doors; no windows; sheets of roof were missing. It was, you know, like [an] abandoned building with people inside; no resources. That was the scenario that we were facing ... you couldn't see the school from the road; you couldn't park here because eh ... the grass was so high; no fences; no gates; no water and then criminals eh ... started walking in and out of the school whenever they liked. So there came a stage when the last principal was run out of the school; they had an acting person here and everything was stuck, everybody would come to school from half past seven until half pass nine; and they would leave from ten o' clock to eleven. I went outside and there were no students and a little later I said, 'Let me check the staff room.' I went to the staff room there were no staff.

The majority of schools in our sample also had to deal with factors relating to a challenging external environment. The rural schools for instance tended to have larger catchment areas which posed particular difficulties not only for pupils and family members to access the schools but also for school leaders to go out and meet with the community. The education levels of parents in rural areas was often below that of township residents and engaging with parents involved overcoming barriers of illiteracy. Rural schools were also sometimes caught up in political processes and change specific to these areas. For example, although they had been either farm or community schools originally, they were now all government owned schools. Nonetheless, they were often obliged to maintain some kind of relationship with the farmer on whose land the school was situated. A further characteristic of these schools was that pupils attending them had more limited choices available to them. This affected the capacity of these schools to be selective in their intake as was the case with some of the township schools where the beginnings of a quasi-market in education was more visible, i.e. there was beginning to emerge a greater 'landscape of choice' for parents and pupils both with the township and beyond (Tikly and 
Mabogoane, 1997; Woolman and Fleisch, 2006 for a discussion of marketization in the South African context).

Even within the township settings there were huge variations in context. Some of these differences relate to the socio-economic and demographic profile of the local school communities. Some for instance served long-established township locations whereas others drew the majority of students from informal settlements that were created in some instances as a consequence of people fleeing political violence in other areas. In one instance, the deputy principal of a township school reported that whenever it rained many dwelling places would literally be washed away. In both the urban and rural areas, the incidence of unemployment was rampant with only limited job opportunities available in the vicinity of the schools. A sense of hopelessness led many youngsters including some of our interviewees to take drugs including dagga (marijuana) and mandrax. The drug culture also invaded many of the schools:

I would say all around there's a problem with drugs so you would find that students are smoking dagga and cigarettes. (HOD, township secondary school)

Despite all of the problems associated with the local environment, pupils from these and more established areas came to school wearing uniforms that however old always appeared in pristine condition. For many parents and pupils caught up in these situations it was clear that school provided a way out of the township and to a better life.

The existence of extreme poverty and of a fluid population including large numbers of recent incomers impacted on crime and violence. The level of crime, although generally high, varied between case study schools. The implication was that although all had to make security of the school a priority, this was more easy to manage in some contexts than in others. In one school, thieves serially broke through the roof (a seemingly favoured route in for thieves in township schools) and had even managed to penetrate the school's strong room. As a consequence the school had to keep valuable items including the photocopier in the district office. Other schools invested significant resources in putting up fences and hiring community members as security guards as well as a range of other innovative practices (see below).

Violence impinged on the day to day realities of the schools. In one school, a boy was stabbed to death in the playground a few days before our visit and we were invited to attend the boy's funeral in the local church. This experience underscored for us the importance of religious beliefs and practices in maintaining social cohesion within the school community in this case through providing an outlet for collective grief and an opportunity to celebrate the achievements of the dead boy who had been a high achiever at school in another institutional setting. Other aspects of the grim realities of township life included incidences of rape and sexual abuse. Some of the schools also reported high levels of teenage pregnancy. 
HIV/AIDS also hung like a dark and menacing cloud around the communities. Nearly everyone had to some extent been touched by an AIDS related death and we sometimes came across instances where teachers had recently died of the disease. It was, however, difficult to elicit information about the impact of HIV/AIDS on school life and there is scope for further qualitative research into this important area.

The local political context was also significant for two reasons. First, local political structures played a role in supporting the schools although this took different forms (see below). Second, the schools were often caught up in politically motivated violence. In one school for instance, some teachers were deterred from teaching there because they had different political affiliations to many members of the local school community. One primary case study school was located near to a hostel for migrant workers in a township who were mainly Inkatha Freedom Party (IFP) supporters whereas the residents were ANC supporters. The hostel had been a focus for violent confrontations between ANC and IFP supporters during the 1980s and 1990s, which over-spilled into the school and caused the school to temporarily close because of the danger posed to the children although by the end of the period of study much of the politically motivated violence had thankfully abated.

\section{Key Dimensions of Effective Leadership}

In this section we report on the findings of our study concerning the key dimensions of effective leadership. The dimensions can be seen as a comparative framework against which similarities as well as differences in leadership approaches between case study schools can be assessed. Some overarching comments relating to leadership effectiveness in the different contexts will be made in the conclusion.

\section{The Structural Dimension: Formal versus Distributed Leadership}

The first dimension to be considered concerns the way that leadership was structured in the schools and the role of the principal. In general, leadership in the schools fell somewhere along a continuum between a formal structure and a more distributed approach in which leadership was dispersed through formal as well as informal means to other members of the school community. Starting with the role of the principal, however, in all cases the role of the principal was pivotal to the change process. In some instances they had been instrumental in establishing the school in its current form. In one rural primary school, for example, the principal had been instrumental in persuading the local farmer to allow for a new school building on his land. In a township school the acting principal had been involved from the inception of the school, which was established by a religious trust. Significantly the principals in the township and rural schools were associated with having taken a lead in restoring a culture of teaching and learning amongst staff and pupils:

Since Mr. N [the Principal] came in our school we have really improved a lot because the learners were carrying weapons, daggas eh ... mandrax; you know anything that 
you can mention ... He just asks you to leave any bad behaviour outside the gates and come in the school as a student ... (Learners in a township secondary school)

Given the nature of the macro and micro contexts of the schools this was a monumental task. Examples of strategies that the principals used are given in the sections below. Sometimes they involved working in partnership with external agencies including local political and religious structures to restore order. In other instances they involved working with communities and even the local farmer (in the case of one rural school) to secure the school from local criminals. In all cases the principals focused on the 'basics' including staff and student discipline and punctuality and the provision of necessary resources.

As noted, distributed leadership is increasingly seen as a feature of effective leadership within the international literature. In the schools in our sample this took a number of forms although it often tended to be understood implicitly rather than explicitly (That is to say, when asked about school leadership, most respondents immediately assumed that we were interested in the principal's role and it was only on further probing that the nature and extent of distributed leadership became apparent.) In keeping with existing models, leadership was typically dispersed not only to deputy heads, heads of department and class teachers but also to pupils, parents and members of the wider community. This happened both as an aspect of formal school processes and of less formal relationships, networks and embedded cultural norms.

In terms of the formal aspects, all of the secondary schools in the sample had established senior management teams. In the case of the township and rural schools in the sample, these had sometimes been only recently established. The opportunities that the SMTs provided for distributing leadership and management responsibilities were appreciated by the principals:

And the introduction of the SMTs has allowed us to make progress because we work together. Management is no longer done by myself alone, we do it as a team. We plan, so that when we see there is a problem we just approach it head on, we don't allow time or space for anything to fester we just deal with the problem straight. (Principal, township secondary school)

Departmental teams were also considered important for similar reasons. Another formal means of distributing leadership was through delegation. In two of the township schools, for instance, responsibility for budgeting was delegated by the principal to a deputy who had skills in this area and had been specifically appointed for this reason. The complex task of timetabling was also often delegated in the schools. The finding is significant because these specific kinds of administrative skills are often at a premium in township and rural schools (DoE, 2004). 
Distributed leadership also involved less formal means of fostering leadership capabilities at all levels of the organization and beyond. For example, a common strategy found in the township and rural schools was to delegate responsibility for implementing OBE to a group of educators. Sometimes these were younger members of staff, who were considered to be more amenable to change and who had recently completed their teacher training and were perceived to be less constrained than some of their more senior colleagues by more traditional styles of teaching. Such responsibility sometimes involved attending workshops, conducting training for other staff as well as taking a lead in teaching the new curriculum. Many of the teachers indicated that their role as educators involved several dimensions of leadership:

I think everywhere you are you are a leader. In the corridor I'm the leader I have to correct them [pupils], in the classroom I'm a leader [] I'm the leader in whatever duty I'm given even if I'm not [formally] given a leadership role I'm the leader ... (Educator in an historically White school)

Some of the perceived value of distributed leadership lay in the opportunities it opened up for staff development. This in turn was considered to have positive implications for organizational development and change management. Examples here included sending staff on workshops organized by the province, e.g. on OBE or the new system of staff appraisal. It also involved less formal arrangements such as developing partnership arrangements with other schools with better qualified teachers that involved passing on skills through informal mentoring arrangements. In one township school, the principal specifically targeted educators in under-performing departments and sent them off to workshops or to neighbouring schools for training.

A distinctive feature of distributed leadership in the sample schools was the sharing of leadership with parents and other members of the 'external' community. In the historically White, Indian and 'Coloured' schools this effectively meant that leadership was extended to the school governing boards who often exercised all of the powers over the budget, appointment of staff etc. that were vested in them in terms of the Schools Act 1996. At the time of the research only a minority of township and rural schools had established school governing bodies (SGBs). Where these had been established, however, the leadership role of governors had been recognized. In the majority of historically African schools we visited, however, this system was still in its infancy and experiencing teething problems (Karlsson et al., 2001; Mabasa and Themane, 2002; Moletsane 2002; Vandeyar, 2002). ${ }^{6}$ In these contexts the distribution of leadership to members of the community happened less formally (see below). 
The Process Dimension: Democratic versus Top-down Decision Making

A key dimension related to the processes of leadership and in particular the extent to which leadership was perceived as being more top-down or democratic in nature. This in turn was connected to the balance between transactional and more transformational approaches to motivating stakeholders behind change. Many of the case study schools appeared overtly democratic in nature. That is to say that on the surface at least they involved different stakeholders in decision making. Classroom teachers were invited to participate in school decision making largely through their involvement in school committees. In many instances this led to a genuine feeling of being involved as the following quote suggests:

I think I must say that many decision because most of the time we do the decision making, the principal does not tell us what to do, she makes us decide on what to do and how it should be done. (Educator, township primary school)

In secondary schools students were given formal leadership positions within the Representative Councils for Learners (RCLs) while in primary schools leadership responsibilities were vested on prefects or monitors. For example, in some of the township schools the SRCs were involved in resolving problems between educators and students. The involvement of staff and learners in decision making needs to be seen as an aspect of historic demands by teachers and learners and their organizations (see above). Scratching below the surface, however, the picture became more complex.

To begin with, the degree to which teachers perceived that their voices were actually listened to varied. For, example, when asked who makes the decisions in her school one educator commented:

The management because they used to come to us with the decision but during the meeting you can easily see that already the decision has been taken. They are just here to tell us but they will ask ... 'do we go for that or not' but you can easily deduce that already the decision is taken.

In Hargreave's (1994) terms this suggests a degree of 'contrived collegiality' rather than genuine collaboration in decision making. It also reflects the reality that not all decisions can be taken by all members of staff all the time, a point that was recognized by a teacher in an historically White school:

Most of it is bottom up, but ... there are times where ... the management has to do specific decisions for the smooth running of the school. (Teacher in an historically White school)

It also became clear that whereas most principals were considered to be 'democratic', 'consultative' and 'good listeners' by staff they were also considered to be more 
top-down and uncompromising in relation to some issues such as staff and student attendance and discipline.

Like our Principal, sometimes he uses democracy, but at times he would say you have to do this thing, like it or not you will have to do it. (Deputy Principal, township secondary school)

Once again it was recognized that at times it was necessary and indeed desirable for the principal to adopt more autocratic approaches to leadership, for example in relation to specific issues such as staff and pupils punctuality and attendance. As with the issue of consulting with staff, however, this needs to be understood in the context of an overwhelming preference on the part of stakeholders for a democratic approach.

Returning to our theoretical framework above, our study suggests that although the leadership styles of the principals can be described as predominantly democratic and transformational in nature, they in fact lay on a continuum between transformational and transactional approaches. Based on our findings it was possible to identify two 'ideal types' of approach each with implications for the way that staff were motivated to implement change. On the one hand, the more transformational principals sought to lead their staff through participatory, democratic means to positions where they were all united behind school values. Staff in these schools was encouraged to develop their own leadership skills and qualities. On the other hand, other principals sought to ensure staff co-operation through more transactional means. Put crudely, staff accepted and promoted the values of the school in exchange for the leadership controlling discipline, raising resources and providing the basic conditions for effective teaching and learning to take place. It could be argued that the two ideal types represent fundamentally different approaches to supporting and motivating staff. Interestingly however, and in keeping with the model of contingent leadership mentioned in previous sections, it was not unusual to find principals adopting one or the other or a mixture of the two depending on the context of the school and the nature of the challenges being faced. In relation to previous examples, for instance, the distribution of leadership around curriculum development can be seen as an example of a transformational approach while at the same school the principal was uncompromising in the use of rewards and sanctions to ensure pupils discipline. Of significance for our study is that although the means were different, both approaches resulted in the achievement of a shared vision and values.

\section{The Practice Dimension: What Do Effective Leaders Prioritize?}

Under this dimension we explore the key areas of practice that the leaders in our sample prioritized. As with the other dimensions some leaders prioritized some areas more than others.

Meaning Making. A key finding of our study concerned the importance of the school leadership in developing a common set of meanings around what the purpose of the 
school was and how this ought to be realized. This was often expressed in terms of a vision informed by an underlying set of values which differed between contexts (Moos et al., 1998; Coleman, 2003). According to some respondents having a shared vision was central to the school's success in mobilizing people around the change process: '... maybe we were preaching the same gospel and they could see that all teachers are saying the same thing, let's change'.

What the vision consisted of varied between settings. High academic achievement was a common theme because it was seen by many as a way out of poverty as was the development of other marketable skills. Many respondents also referred, however, to the role of the school in creating the 'whole person'. This included attributes such as a good sense of morality, the inculcation of citizenship skills, respect for elders and for authority, understanding gender equity, respect for Christian and other religious values, respect for self and personal hygiene. In order to achieve these outcomes, respondents emphasized the role of the school in promoting excellence and inculcating discipline. They also discussed the importance of providing the necessary resources to support these outcomes.

However, creating a vision based on a common set of values was not always easy (see also Full- an's [2003] discussion of the difficulty of creating shared values or in his terms, 'moral purpose'). At times it involved the leadership of the school negotiating sometimes contradictory values between different stakeholders, the schools and the national and provincial governments and even local political parties. A good example was around the abolition of corporal punishment. In implementing legislation banning corporal punishment many of the principals in our study had to engage head on with the deeply held belief in many of the communities and amongst staff that schools should not 'spare the rod' if their children were to be well disciplined. In some instances this meant sweeping the issue under the carpet. It was quite clear on scratching below the surface that the practice of corporal punishment was continuing to take place in some of the schools. As one HOD put it:

Talking traditionally or culturally, we [the 'African community'] believe that kids need to be given some sort of a hiding so as to be in line or adhere to instructions, but that is a hot debate that we are actually debating with the parents, so as not to be on the wrong or caught on the wrong side with the department [of education].

In fact, the schools had no choice other than to obey changes in the law which had outlawed corporal punishment. The leadership of the school, however, had to explain this to parents and to convince them that their children would still be subjected to effective, alternative forms of discipline. By doing this the schools were able to build on a tradition of working with the local community to ensure good discipline (see below). 
A further example relates to the implementation of OBE. All the schools were sensitive to the threat to existing values held by some teachers and parents who had been schooled under apartheid education with its emphasis on hierarchical, content driven and teacher centred approaches and rigid assessment regimes. Many of the Principals, senior managers and educators in the schools we visited took considerable time explaining the benefits of the new curriculum to teachers and parents and how it would advantage their children. This was necessary to dispel a view held by some parents that the curriculum only benefited wealthier children and that it could only be successfully implemented in advantaged and well resourced schools. Some leaders emphasized the role of parents in actually determining the curriculum.

At the major meetings we call parents and they decide what they want the children to be taught, so at an early age to grade seven we able to guide them so we can help enrich as I said in the beginning the morals that they were taught. So whatever they gave us, 'we want our children to be taught this', now we know that when we plan our lessons, we need to plan our lessons along those lines. (Educator, township secondary school)

Others emphasized the important role that parents had to play in supporting their children learning as the following quote exemplifies:

Because we know that OBE is good not just for the gifted, that it allows our children to develop their talents for financial independence we are now very conscientious about supervising our children's' homework. (Parent, township primary school)

A third example concerns that of gender equity. In attempting to implement gender equity and in particular to promote more women to senior management positions, some of the principals had to contend with negative attitudes among some male teachers and the perception that females were being unfairly favoured in the promotion stakes regardless of whether this was true or not in practice.

Putting Value in the 'Basics'. Despite the differences in values amongst stakeholders it was possible to identify a common element in all of the successful schools that we have called 'putting value in the basics'. This meant first and foremost paying attention to creating the conditions where teaching and learning could occur. For example, when asked what his school valued the most a teacher in a rural secondary school replied:

... to foster the culture of teaching and learning, basically. That's the underlying principle behind what we do here. Just to make sure that everybody comes to school and gets some kind of education at the end of the day.

Similarly, a teacher in a township secondary school had this to say: 
Effective teaching,-effective learning ... we've got a fancy vision statement. Now I want to unpack that for you ... good teaching, good learning in a disciplined environment.

In many of the case study schools, principals spent a good proportion of their time ensuring teacher attendance and punctuality:

We often hear him disciplining educators who have been absent from school; he requires a doctor's certificate. He stresses that he is the principal and they must obey the rules. They should keep in mind that their responsibility is to teach children. Everyone respects him, for example, when the bell rings all learners obey by picking up all papers that are lying around and put them into bins. (Parents, township secondary)

Ensuring that the basic resources required including text books, learning materials and other essential equipment was available was another important activity for principals as well as for heads of department and individual teachers. Obtaining additional resources in contexts of stringency required considerable imagination and vision together with the ability to convince potential donors of the value of contributing to the school (see below). Principals also spent considerable time and effort ensuring fees were collected and in mobilizing additional funds for the schools.

An emphasis on the basics often meant that senior managers patrolled the school buildings ensuring learners arrived on time for their classes. In one case the principal of a township secondary school started to lock the gates having issued several warnings to pupils. In the secondary schools it also involved spending many additional hours outside of normal school hours, running 'study sessions'. This involved students remaining at school after (or in some cases before) 'official hours' to do homework and going over their work under the supervision of teachers who took turns running the sessions. This was considered particularly important in the disadvantaged settings where pupils were unlikely to be able to study effectively at home or where their parents or carers were illiterate or unable to give study support.

The pupils were often highly appreciative of the individual effort of the principals and other senior managers in encouraging and supporting their studies and taking a personal interest in their work and progress. Ensuring discipline also meant working closely with parents and other community structures to help enforce the discipline of the students. This coincided with the priorities of parents and teachers and also of pupils themselves.

Working with the Community. As noted, many of the township and rural schools unlike the more historically advantaged schools had difficulties in establishing SGBs. In many cases, however, informal ways of engaging the leadership of parents and of 
the wider community were critical particularly in the areas of finance, security and/or discipline.

Unlike in the more historically advantaged schools, varying levels of poverty directly impacted on the quality of education available because of the difficulties schools encountered in raising fees. In our study the typical amount of fee collected from parents varied between about R4O and R200. This contrasts to fees for some historically advantaged schools which can amount to between R1000- 20000. Nonetheless, the schools we visited typically managed to collect fees from between 40-60 per cent of parents. This is a critical point. In township and rural schools, whereas the government typically pays most of the teachers' salaries and for plant maintenance and upgrading, money raised from fees forms a significant proportion of the money spent on learning materials, equipment and furniture all of which are critical components of a quality education. The limited capacity to raise fees contributed directly to the lack of resources in some instances. For example, in one primary school trying to implement a new English curriculum based on OBE, the only resource available was a plastic box containing old magazines. An educator in a township secondary school commented:

Sometimes you find that there is a book that you would love all of them to buy and find that most of the time you have to provide information, write most of the time on the board, there's a lot of things that we need.

Not surprising then that all of our effective principals expended considerable time and energy worrying about how to collect fees and to raise money from sponsors (Lumby, 2003). Indeed, despite the difficulties, some of the township and rural schools managed to maintain high levels of resourcing that contributed significantly to the quality of education that they were able to maintain. Most of the effective secondary schools, for instance had fully equipped science labs and computer suits which they took pride in showing off to guests and visitors. The availability of resources depended on the entrepreneurial abilities of the principals and particularly on their ability to secure sponsorship from local companies. This proved to be a virtuous cycle with companies relatively happy to invest in successful schools.

Developing links with the community extended well beyond issues of resource however. It was also considered critical for supporting teaching and learning more generally. This applied for instance to attendance and if the learner was experiencing a particular problem:

Ja, we do involve parents ... for instance so that when the learner is absent we want to make sure from the parent [that the absence is legitimate] ... of course we can't phone them because they don't have phones at home but we write a letter to the parent to come and explain why the learner has been absent for so long. If the learner has got a problem in class we call the parent and we arrange a meeting with the parent. 
Discipline was another important area in which parental co-operation was typically sought (although as noted this often involved engaging in tricky discussions around corporal punishment). Significantly, parental involvement was considered important for supporting pupil learning outside of school:

I ... think that one has got to be closely related to the parents out there because the students work does not end in the school. In the school we give them direction, we tell them that this is what we are supposed to be doing, when they go out there they need to be doing what we have told them to do and when the parents cannot do that, then the work is not going to be done.... That is why we need to motivate their parents and show them the importance of educating their children.

Many schools organized parents meetings typically once or twice a year. Compared to the historically advantaged schools in our sample, however, attendance was not always high in the township and rural schools and proved problematic for some parents. Some of the schools adopted innovative strategies to communicate with parents. In one township secondary school meetings were targeted at specific groups of learners in standard 12 and this proved more successful in attracting parents. In another rural school the principal spent significant amounts of time visiting parents who sometimes lived many kilometres from the school in remote villages as he felt this was the key to getting them to better understand their role in supporting their children's learning especially given the high incidence of illiteracy among the rural community. During his visits he would explain in simple terms how parents could support their children's learning through providing basic nutrition at home and through developing in them an understanding of the requirements of the curriculum. As a consequence of his success in raising achievement and examination results, pupils had also started to attend from the township which was a considerable distance away.

Getting parents involved in their children's education, especially where this had not been practiced in the past and in contexts of poverty involved both transactional and relationship-based approaches in which the community not only gave to the school but where the school was also perceived to give to the community. For example, all of the effective primary schools provided support to poor communities through running the government funded feeding scheme. Other schools organized fund raising activities to support poorer students with basic equipment. One school especially took pride in assisting the poorer members of the community and saw it as a necessary part of its success in raising achievement. According to one deputy principal of a township school:

We try to improve the standard of the community where we live in because these people are so poor. In winter we collect old clothes and keep them in the school. Then one day we give them to the community because there are children who come to school without wearing ajersey or something in winter, so we cater for them as well. 
We ask for donations from outside because there are children who come to school without even eating a slice of bread. We invite those parents so we can see whether they are really battling ...

School security was another area where a transactional approach proved effective. Some schools as mentioned above invested significant resources in putting up fences and hiring community members as security guards. There were also instances of extremely innovative practice. At a rural school for instance, the principal had struck a deal with the local white farmer. Through his high standing in the community which was built on his success as a principal and his involvement in the liberation struggle, the principal was able to broker the safety of the farmer and his family in exchange for the local farm watch keeping a close eye on the school. The farmer had also erected a high electric fence around the school and as a result of these actions the school was able to keep its state of the art computer suite safe. In one of the township secondary schools, the school had provided accommodation for a local policeman in a house overlooking the school in exchange for him keeping an eye on it. They had also donated a plot of land overlooking the school to members of the community. In return, the people working the land kept an eye on the school. Although not faced with the same level of crime as some of the township schools, a similar strategy was used in one of the historically advantaged schools in our study where the principal used his links with the local police force to ensure that the school was regularly patrolled at night.

The local political context was also significant for as mentioned above, local political structures played a role in supporting the schools although this took different forms. In one rural school a returned exile and former member of Umkhonto we Sizwe, 7 had joined the governing body and played a critical role in helping to motivate for the establishment of the school and in drumming up parental support for the school and encouraging parental involvement. He also visited the school regularly helping the school leadership to enforce attendance. In another township school a similar role was adopted by the local branch of the IFP which had considerable influence amongst the youth residing in the informal settlements.

As already mentioned, another aspect of township life in the late nineteen nineties and early in the new millennium were the high levels of politically motivated violence. Although the violence had abated, at the time of the research some schools are still dealing with the aftermath. Teachers had been deterred from taking up a post in one school because they had different political affiliations to other members of the school community. Local political structures had been important in guaranteeing the safety of these teachers by ensuring that party members did not attack them. Another primary case study school was located near to a hostel for migrant workers in a township who were mainly IFP supporters whereas the residents were ANC supporters. The hostel had been a focus for violent confrontations between ANC and IFP supporters during the 1980 s and 1990s, which over spilled into the school and 
caused the school to close. The principal quickly realized that many of the children at the school had in fact been fathered by hostel dwellers and she exploited this to get their support for a truce that would guarantee that the school could reopen. She began to run adult basic literacy classes for the hostel dwellers so that they could assist with their children's learning and got them to come into school to teach the children traditional Zulu singing and dancing. In this way, the principal almost single-handedly brought peace to the community.

What the above examples all demonstrate is the extent of informal school community links in the township and rural schools and the centrality of these for effective leadership. This brings to mind concerns by authors such as Boardman (2001) and Lam and Punch (2001) that most schools are depriving themselves of the potential benefits that engaging with leaders in the wider community can bring. In a study on why some principals succeed and others struggle when faced with innovation and transformation Prew (2007: 448) similarly found that 'the successful principals were particularly effective at working with the surrounding community on its own terms'. In South Africa, these concerns are reiterated in claims by the former Minister of Education, Professor K. Asmal, in the Tirisano document that: '... an education system for the 21st century cannot be built by a small group of people, or even the Government, working alone'. It calls for a massive mobilization of parents, learners, educators, community leaders, non-governmental organizations (NGOs), and the private sector, motivated by a shared vision (Department of Education, 1999). A key challenge for schools as they seek to establish more formalized structures is to build on existing links in a way that will continue to benefit learners.

\section{The Personal Dimension: Qualities of Effective Leadership}

The focus of the analysis thus far has been largely on the structures, processes and practices associated with effective leadership in our sample schools. Part of our approach, however, was to also seek to identify some of the personal qualities and values held by the leaders. The principals not surprisingly demonstrated a range of leadership qualities many of which were shared by other people in leadership positions in the school community. One of those identified was personal integrity or 'walking the talk' (Day et al., 2000). For example, many of the respondents reported that the principals worked longer hours than the rest of the staff-reporting for work earlier and leaving the premises later. They were exemplary in carrying out their own teaching, administrative and management tasks. They were often upstanding individuals who held considerable respect within the wider community. They demonstrated an obvious commitment to assisting learners and showing concern for community welfare. Another quality related to the issue of integrity was financial trustworthiness and acumen, i.e. that leaders were trusted with the money raised from fees and other sources and it was perceived that this money was used wisely. This is particularly significant for schools located in disadvantaged areas where parents often struggled to pay their school fees. (In one township school, for example, parents claimed that the current Principal had reduced the amount of fees collected to 
R2o per month from R3o but had still managed to finance fencing around the school, a task which the previous principal had promised them but failed to deliver throughout his five year tenure at the school.)

The principals were also perceived to value their relationships with staff and to trust them. They spent a lot of effort encouraging staff. One principal regularly visited staff in their homes and many had an open door policy allowing staff to approach them with problems. Respondents also commented on the level of compassion and understanding shown by principals. All of these inter-personal factors were considered important for motivating staff.

As noted, the principals were expected to be democratic but also firm when necessary: She's damn good. She's firm, whenever she says something she stands by the word. She's not afraid to say something, you know, even if it is not nice, to us people who this thing is directed to. One word is, she is firm. (Educator, township secondary school)

The principals were also expected to be even handed and fair in their dealings with others. As one HOD put it, they are expected to 'treat everybody the same, respect everybody you know'.

Good communication was consistently identified as a characteristic of effective leadership. Principals were often seen by the respondents as official 'gate-keepers' of change related information and as being primarily responsible for acquiring related resources and mobilising support from the school community. These qualities in turn relied on effective communication. The communication role of the school leadership is especially significant in township and rural settings where formal sources of information including education offices, post offices, the Internet, telephones and faxes are less readily available than in other settings. Stakeholders valued being given timely information regarding changes. This is understandable considering that individuals may only begin to 'comply' and cope when and if they are well informed of expectations. As a teacher in a historically 'Coloured' school put it:

We do get circulars. Our Principal makes sure that if there are changes ... he goes to the secretary office and brings the circular in time and he makes sure that we get them.

Besides the ability to effectively disseminate information, leaders were also required to be good listeners. As one principal reported:

I don't see myself as a leader, I see myself as a follower because the people have got to show me the way then I ensure that they are following the right way, so it's not always being in front, sometimes I must listen to what they are saying not always telling them what to do. 
Partly as a result of the esteem in which they were held, the leaders were perceived to act as role models to others. This was important, for instance in projecting a positive rather than a negative view of change. Being a good role model was also identified as an important characteristic of senior managers, classroom teachers and learners including prefects and monitors. A commonly held view expressed by a female teacher in a rural primary school for instance was:

Yes we do see ourselves as leaders, they look up to us. I mean in general if you are teacher just standing up in front of them they see you as their leader. You have to lead by example. Everything you do, they will do. I have to earn their respect. Everything I do I make sure that there are followers looking up to me, so we are in other words leaders. So we must be leaders in order to earn good followers. You cannot expect them to behave good if you don't. So, we have to lead by example.

Effective leadership styles in the township and rural schools also appeared to have a gender dimension. It was not uncommon for instance for female leaders in our study to be characterized as having 'nurturing' qualities. For example, in one township lower primary school led by a female principal the nature of relationships between the principal, staff, parents and pupils was described by several respondents as nurturing and supportive. One parent reported an incident in which the principal had driven her epileptic child home after this child had experienced a seizure. Such nurturing was also conveyed by a female teacher in a township secondary school in response to a question on how the teachers viewed their teaching roles:

... we female teachers are like their mothers. I mean at home when you have a problem you start with your mother and then maybe after that you'll come to your brother or father but first they'll come to the female teachers because we are also very confidential, we make sure that we are not speaking (pass matters confided to us) to other teachers. If you are going to pass the information you go to the Principal and he will refer you to a social worker but we don't discuss amongst ourselves, we are very confidential.

Similarly, a female learner in a primary school stated:

So it's like when I look at them [the teachers] it's like a motherly role, in every way that I need them they must be there for me. That is how I look at the role of a teacher.

Some respondents noted that female leaders also faced particular difficulties on account of being female running up against sexist attitudes and beliefs and having their authority called into question by some male members of staff.

While female principals were sometimes described as 'motherly', a number of male principals were described as 'fatherly' and protective in terms of issues such as school security. Although these views of female and male leadership qualities appeared as a 
theme from our respondents there is inevitably a danger of gender strereotyping implicit in such characterizations. More research is needed into the complex dynamics underpinning gendered leadership practices and their relationship to cultural norms and values and to broader dynamics of power relations between men and women.

\section{Conclusion}

In this concluding section we will summarize our main findings and identify areas for further research. Rather than present one over-arching model or a list of key characteristics we have sought to identify key dimensions of effective leadership that have served as a framework for comparing our findings with evidence from the wider literature as well as analysing similarities and differences in effective leadership practices between our case study schools.

Some of the findings from our study concerning the nature of effective leadership were consistent with trends in the western literature (Leithwood et al., 1999; Day et al., 2000; Fink and Brayman, 2006). Here the emphasis has been on the centrality of vision and values; the importance of transformational approaches to motivating others; the distributed nature of effective leadership; the importance of a focus on the instructional dimensions of leadership; managing across the boundaries and of personal qualities such as integrity and communication skills. As we have seen these aspects often took on a different form and emphasis in our case study schools related to the broader context of change. For instance, in the majority of our case study schools leaders demonstrated a mixture of top down, transactional approaches and more democratic transformational ones reflecting on the one hand the realities posed by local settings and the broader process of transformation from authoritarian to more democratic practices. Much more than appears to be the case in the western literature there is a focus in the case study schools on what we have described as the 'basics': ensuring not only that effective teaching and learning take place but that the underlying conditions to permit this are present including necessary levels of resource and teacher and pupil attendance, punctuality and discipline. Here, our study is more in line with the views of scholars such as Jansen and with the findings of effectiveness studies from low income countries ( $\mathrm{Yu}, 2007)$. Our study adds to existing understandings through providing evidence of the role of leadership in ensuring these conditions. Finally, the majority of schools in our sample had to work intensively with the community in ways related to the local context to mobilize resources and to broker a safe and secure environment for learners to learn. Bringing the best out of our most dis- advantaged learners requires that the school engages with the contexts that they are from and seek ways to actively empower parents with ways to support their children's learning. This involves engaging sensitively with a range of cultural values around the purpose of education and to find ways to harness the obvious enthusiasm amongst the most disadvantaged sections of society for education. Many of the leaders in our study expended a good deal of time doing just this. 
There were of course differences in the nature of effective leadership between schools related to differences in local contexts. Thus although the historically advantaged schools had to deal with challenges related to the local context such as an influx of non-traditional learners and a growing reliance on locally mobilized resources their contexts were more in keeping with those reported in the western literature. This may explain why the trends in effective leadership more closely followed western patterns although more comparative research is required in this respect. There were also differences between the township and rural schools with leaders in the latter schools and even between township schools dealing with differing populations and those impacted on the things that leaders had to prioritize as we have seen.

Although we believe our study has developed important insights into an under-researched area we also recognize shortcomings and areas for further research. For example, subsequent studies could consider broadening the scope of what is taken to be 'effective leadership' to embrace other potential outcomes from education besides academic achievement and change management. (It was also clear that many of the schools continued to use corporal punishment. What would effective leadership in schools that did not use corporal punishment look like?) We have also identified specific areas such as the impact of HIV/AIDS, democratic governance and gender as areas for further investigation. In line with more recent work on sustainable leadership (Hargreaves and Fink, 2006) it would be useful to focus on the mechanisms by which effective leadership practices become embedded over time which would require a more longitudinal approach than was possible in our study. This would also entail engaging with the role of leadership training and in areas such as succession planning. In our study we hope to have highlighted the benefits that can be gained through focusing on schools that although historically disadvantaged contain within them a wealth of knowledge and expertise about how to bring about positive change. Finally, we have sought to develop a framework for comparing effective leadership across different contexts. It would be useful to further examine the utility of the framework though conducting comparisons across more case study sites in South Africa and internationally.

\section{Notes}

1. In 1994, the government spent R31.8 billion on education; in 2006, the budget allocation was R92.1 billion.

2. The view of the team was that a comparative reflection on leadership similarities and differences in these schools would provide a useful springboard for the development of further understanding of leadership effectiveness and change in the province as a whole.

3. The initial data gathering was by the authors in four schools in the Durban area. This served as a pilot for the subsequent gathering in the nine other schools spread over the KwaZulu-Natal province.

4. Four strategies were used to ensure the trustworthiness of the research process and results. First, different data sources were triangulated to provide a check on 
different factual information, e.g. relating to school and class sizes, staffing, attendance, dates and timings of significant events, etc. Second, wherever possible, transcripts were validated with respondents. This was particularly important where the recordings of interviews were muffled or unclear. Third, during the original pilot study the team discussed emerging findings and interpretations with respondents during a dissemination event to ensure our interpretation matched those of respondents. The team also met regularly to discuss our approaches to analysis, themes emerging form the data and to be sure that we were consistent in the way that we interpreted the data.

5. What most differentiates grounded theory from much other research is that it is explicitly 'emergent'. Mer- riam (1998) has urged caution in combining a case study and grounded theory design lest the case study design is insufficiently flexible to allow for theory to genuinely 'emerge' from the data. Conducting our field work in phases with a pilot phase allowed us to adapt the case study methods in the light of emerging theory and to test new cases and modify instruments. Following Merriam we have attempted to keep the discussion of theory substantive and specific to the data gathered in the case study. We attempted to allow the theory to emerge 'quickly' at first and then to compare data with emerging themes and literature as part of an iterative process. Through theoretical sampling of different contexts and groups of respondents we also sought to maximize the similarities and the differences of information (Cresswell, 2003: 14).

6. Our findings are also in contrast to other findings. For example, the Department of Education (2004) on school governance and Bush et al.'s (2004) study, suggest that the system of school governance is past its infancy. We argue that there is a need for caution in interpreting and generalizing the findings from these reports. First, Bush et al.'s study was conducted in the Gauteng's province, a province whose general wealth, literacy and participation is, except for the Western Cape, ahead of the other provinces. Also, although generally positive, findings in the Ministerial Report Review, did point to areas of concern such as scant election participation resulting in SGB compositions that were not always representative of the general schools' populations.

7. Umkhonto we Sizwe ('Spear of the Nation') was the name given to the armed guerrilla wing of the ANC during the liberation struggle.

\section{Acknowledgements}

The pilot for the research was originally funded as part of a British Council link between researchers at the Universities of KwaZulu Natal and Bristol in the UK that ran between 2000 and 2005. The larger scale project ran between 2003 and 2006 and was funded by the National Research Foundation of South Africa. The authors would like to express their sincere thanks to these funders. We were also assisted in our data collection by Kantha Chetty and in identifying schools by Sam Ntuli and Pontso Moorosi. We would like to thank them for their efforts. We would like to thank in particular the participating Principals, educators, learners and parents who gave up their valuable time to contribute to the study. Our acknowledgement and respect 
must go to the many practitioners who continue to devote their energies to educational transformation in South Africa. Finally, we would like to acknowledge the support of our colleagues who have provided helpful comment and feedback on various drafts of this article including George Oduro and Jo-Anne Baird. The authors take full responsibility for the views expressed in this article. 


\section{References}

Asmal, K. (1999) 'Call to Action: Mobilising Citizens to Build a South African Education and Training System for the $21^{\text {st }}$ Century'. Statement in South African Parliament, GCIS: South Africa Yearbook 2001/2002. Available at: http://www.gcis.gov.za/documents/publications/yearbook/index.html. Accessed 23 December 2007.

Boardman, M. (2001) 'The Value of Shared Leadership: Tasmanian Teachers' and Leaders' Views', Journal of the Commonwealth Council for Educational Administration and Management 29(3): 2-10.

Burns, J.M. (1978) Leadership. New York: Harper \& Row.

Bush, T., Joubert, H.J., Van Rooyen, J.W. and Heystek, J. (20004) 'Leadership and Governance in Gauteng schools' . Paper presented at the EMASA conference, Johannesburg, March, 2005.

Calitz, L. (2002) 'Leadership for Change in Education: The South African Perspective' , in L. Calitz, O.L. Fuglestad and S. Lillejord (eds) Leadership in Education. Sandown: Heinemann.

Chisholm, L. (2004) 'Introduction' , in L. Chisholm (ed.) Changing Class: Educational and Social Change in Post-apartheid South Africa. Cape Town: Human Science Research Council Press.

Christie, P. (1997) 'Globalisation and the Curriculum: Proposals for the Integration of Education and Training in South Africa', in P. Kallaway, G. Kruss, A. Fataar and G. Donn (eds) Education after Apartheid: South African Education in Transition. Cape Town: UCT Press.

Christie, P. (2001) 'Improving School Quality in South Africa: A Study of Schools that Have Succeeded Against the Odds' , Journal of Education 26: 40-65.

Coleman, M. (1994) 'Leadership in Educational Management' , in T. Bush and J. West-Burnham (eds) Prin- ciples of Educational Management. Harlow: Longman.

Coleman, M. (2003) 'Theories of Leadership' , in M. Thurlow, T. Bush and M. Coleman (eds) Leadership and Strategic Management in South African Schools. London: The Commonwealth Secretariat.

Cresswell, J.W. (2003) Research Design Qualitative and Quantitative and Mixed Method Approaches, 2nd edn. Thousand Oaks, CA: SAGE.

Crossley, M., Herriot, A., Waudo, J., Mwirotsi, M., Holmes, K. and Juma, M. (2005) Research and Evaluation for Educational Development learning from the PRISM Experience in Kenya. Oxford: Symposium.

Day, C., Harris, A., Hadfield, M., Tolley, H. and Beresford, J., (2000) Leading Schools in Times of Change. Buckingham: Open University Press.

Department of Education (1996a) National Evaluation: Culture of Learning Programme: Final Report. Pre- toria: Department of Education.

Department of Education (1996b) Changing Management to Manage Change in Education: Report of the Task Team on Education Management Development. Pretoria: Department of Education. 
Department of Education (1996c) The South African Schools Act. Pretoria: Department of Education.

Department of Education (1999) Tirisano. Pretoria: Department of Education.

Department of Education (2004) Review of School Governance in South African Public Schools. Report of the Ministerial Review Committee. Pretoria: Department of Education.

Edmonds, R. (1979) 'Effective Schools for the Urban Poor', Educational Leadership 37: $16-18$.

Fink, D. (2000) Good Schools/Real Schools: Why School Reform Doesn's Last. New York: Teachers College Press.

Fink, D. and Brayman, C. (2006) 'School Leadership Succession and the Challenges of Change', Educational Administration Quarterly 42(1): 62-89.

Foskett, N. and Lumby, J. (2003) Leading and Managing Schools: International Dimensions. London: Paul Chapman Publishing.

Fullan, M. (2003) Changing Forces with a Vengeance. London: RoutledgeFalmer.

Haig, B.D. (2001) 'Grounded Theory as Scientific Method'. Availab;e at: www.ed.uiuc.edu/EPS/PES-year- book/95_docs/haig.htlm-35k. Accessed 28 June 2003.

Harber, C. (2001) State of Transition: Post-apartheid Educational Reform in South Africa. Oxford: Symposium.

Hargreaves, A. (1994) Changing Teachers, Changing Times: Teachers' Work and Culture in the Postmodern Age. London: Cassell.

Hargreaves, A. and Fink, D. (2006) 'Sustainable Leadership', Journal of Educational Change 7(1-2): 109-11.

Harley, K., Barasa, F., Bertram, C., Mattson, E. and Pillay, K. (2000) 'The Real and the Ideal: Teachers' Roles and Competencies in South African Policy and Practice', International Journal of Educational Development 20(4): 287-304.

Heneveld, W. (1994) Planning and Monitoring the Quality of Primary Education in Sub-Saharan Africa. Washington, DC: World Bank, Human Resources and Poverty Division.

Heneveld, W. and Craig, H. (1996) Schools Count: World Bank Project Designs and the Quality of Primary Education in Sub-Saharan Africa. Washington, DC: World Bank.

Horner, M. (2003) 'Leadership Theory Reviewed", in N. Bennet, M. Crawford and M. Cartwright (eds) Effective Educational Leadership. London: Paul Chapman.

Jansen, J. (2001) 'Explaining Non-change in Education Reform after Apartheid: Political Symbolism and the Problem of Policy Implementation', in Y. Sayedand J. Jansen (eds) Implementing Education Policies: The South African Experience. Cape Town: UCT PRESS.

Jansen, J.D. (2002) 'Policy as Political Craft: Explaining Non-reform in South African Education 1994-2000', Journal of Education Policy 17(2): 199-215.

Jansen, J. (2005) 'Targeting Education: The Politics of Performance and the Prospects of "Education For All"', International Journal of Educational Development 25(4): 368-80. 
Karlsson, J., McPherson, G. and Pampalis, J. (2001) 'A Critical Examination of the Development of School Governance Policy and its Implications for Achieved Equity', in E. Motala and J. Pampalis (eds) Education \& Equity: the Impact of State Policies on South African Education. Sandown: Heinemann.

Latchem, C. and Hanna, D.E. (2001) 'Lessons for the Future', in C. Latchem and D.E. HLam, Y.L.J. and Punch, K.F. (2001) 'External Environment and School Organizational Learning: Conceptualizing the Empirically Neglected', Journal of the Commonwealth Council for Educational Administration andMan-agement 29(3): 28-39.

Leithwood, K., Jantzi, D. and Steinbach, R. (1999) Changing Leadership for Changing Times. Buckingham: Open University Press.

Lockheed, M.E. and Levin, H.M. (1993) 'Creating Effective Schools', in H.M. Levin and M.E. Lockheed (eds) Effective Schools in Developing Countries, pp. 1-19. London: Falmer Press.

Lumby, J. (2003) 'Culture change', Educational Management \& Administration 3(2): 159-74.

Mabasa, T. and Themane, J. (2002) 'Stakeholder Participation in School Governance in South Africa', Perspectives in Education 20(3): 111-16.

MacBeath, J., Moos, L. and Forrest, J. (1998) 'Time for a Change', in J. MacBeath (ed.) Effective School Leadership: Responding to Change. London: Chapman.

Merriam, S. (1998) Qualitative Research and Case Study Applications in Education, San Fransisco, CA: Joset-Bassey.

Moos, L., Mahony, P. and Reeves, J. (1998) 'What Teachers, Parents, Governors and Pupils Want from their Heads', in J. MacBeath (ed.) Effective School Leadership: Responding to Change. London: Chapman.

Moletsane, R. (2002) 'Swimming Against the Tide: External Intervention in a "Non-resilient" School', Journal of Education 27: 117-36.

Morley, L. and Rassool, N. (1999) School Effectiveness: Fracturing the Discourse. London: Falmer.

Mortimore, P., Sammons, P., Stoll, L., Lewis, D. and Ecob, R. (1988) School Matters: The Junior Years. London: Open Books.

Mullford, B. (2003) 'Leadership in Education: Losing Sight of our Interests', in N. Bennett, M. Crawford and M. Cartwright (eds) Effective Educational Leadership. London: The Open University in association with PCP.

Ngcobo, T.M. (2005) 'The Relationship between Academic Performance, School Culture and Leadership in Historically Disadvantaged African Township Secondary Schools: Implications for Leadership', PhD thesis, University of KwaZulu-Natal.

Oduro, G. (2006) 'Headteachers Role Modelling in African Schools: the Challenge of Communal Values', paper presented to 9th EMASA Annual Conference, Limpopo, 6-8 February 2006.

Parshiardis, P. (2001) 'Secondary Principals in Cyprus: The views of the Principal versus the Views of the Teachers-a Case Study', Journal of the Commonwealth Council for Educational Administration and Management 29(3): 11-27. 
Prew, M. (2007) 'Successful Principals: Why Some Principals Succeed and others Struggle When Faced with Innovation and Transformation', South African Journal of Education 27(3): 447-62.

Purkey, S. and Smith, M. (1983) 'Effective Schools: A Review', The Elementary School Journal 83: 426-52.

Riley, K. (2000) 'Leadership, Learning and Systemic Reform', The Journal of Educational Change 1(1): 29-55.

Riley, K. and Macbeath, J. (2003) 'Effective Leaders and Effective Schools', in N. Bennett, M. Crawford and M. Cartwright (eds), Effective Educational Leadership. London: Paul Chapman.

Rosener, J.B. (1990) 'Ways Women Lead', Harvard Business Review November/December: 119-25.

Russell, M. (2003) 'Leadership and Followership as a Relational Process', Educational Management \& Administration 3(2): 145-57.

Sammons, P., Hillman, J. and Mortimore, P. (1995) Key Characteristics of Effective Schools: A Review of School Effectiveness Research. London: Office for Standards in Education.

SAInfo (2007) Available at: http://www.southafrica.info/. Accessed 21 December 2007.

Scheerens, J. and Bosker, R.J. (1997) The Foundations of Educational Effectiveness. Oxford: Pergamon.

Sergiovanni, T. (2005) Rethinking Leadership: a Collection ofArticles .Thousand Oaks, CA: Corwin Press.

Singh, P. and Lokotsch, K. (2005) 'Effects of Transformational Leadership on Human Resource Management in Primary Schools', South African Journal of Education 25(4): 279-86.

Soudien, C. (2004) "'Constituting the Class": an Analysis of the Process of "Integration" in South African Schools', in L. Chisholm (ed.) Changing Class: Educational and Social Change in Post-apartheid South Africa, pp. 89-114. Cape Town: Human Science Research Council Press.

Soudien, C. (2007) 'The "A" Factor: Coming to Terms with the Question of Legacy in South African Education', International Journal of Educational Development 27: 182-93.

Strauss, A.L. (1970) 'Discovering New Theory from Previous Theory', in T. Shibutani (ed.) Human Nature and Collective Theory, Englewood Cliffs, NJ: Prentice Hall.

Strauss, A. and Corbin, J. (1990) Basics of Qualitative Research: Grounded Theory Procedures and Techniques. Newbury Park, CA: SAGE.

Taylor, N., Muller, J. and Vinjevold, P. (2003) Getting Schools Working: Research and Systemic School Reform in South Africa. Cape Town: Pearson Education South Africa.

Tellis, W. (1997) Application of a Case Study Methodology: the Qualitative Report. Available at: http:// www.nova.edu/ssss/QR/Qr3-3/tellis2.htlm. Accessed 23 December 2007. 
Tikly, L. (2003) 'Governmentality and the Study of Education Policy in South Africa', Journal of Education Policy 39(2): 161-74.

Tikly, L. and Mabogoane, T. (1997) 'Marketisation as a Strategy for Desegregation and Redress: The Case of Historically White Schools in South Africa', International Review of Education 43(2-3): 141-61.

Tikly, L., Ngcobo, T. and Moorosi, P. (2005) 'Leadership and Change in South African Schools: Partnership with the External Environment'. Paper presented to the Education Management Association of South Africa (EMASA) conference, Johannesburg, 11-13 March 2005.

Townsend, T. (1994) Effective Schooling for the Community. London: Routledge.

Vandeyar, S. (2002) 'School Governing Bodies: Constructive Change Agents of Leadership?, in L. Calitz, O.L. Fuglestad and S. Lillejord (eds) Leadership in Education.Sandown: Heinemann.

Velez, E., Schiefelbein, E. and Valenzuela, J. (1993) Factors Affecting Achievement in Primary Education: A Review of the Literature for Latin America and the Caribbean. Washington, DC: Department of Human Resources Development and Operations Policy, World Bank.

Weber, G. (1971) Inner School Children Can Be Taught to Read: Four Successful

Schools. Washington, DC: Council for Basic Education.

Welton, J. (2001) 'Building Capacity to Deliver Education in South Africa', in Y. Sayed and J. Jansen (eds) Implementing Education Policies: The South African

Experience. Cape Town: UCT PRESS.

Woolman, S. and Fleisch, B. (2006) 'South Africa's Unintended Experiment in School Choice: How the National Education Policy Act, the South Africa Schools Act and the Employment of Educators Act Create the Enabling Conditions for Quasi-markets in Schools', Education and the Law 18(1): 31-75.

Yin, R.K. (2003) Case Study Research: Design and Methods, 3rd edn. London: SAGE.

Yu, G. (2007) 'Research Evidence of School Effectiveness in Sub-Saharan African

Countries', Available at: http://www.edqual.org/research/seeqlit2007.pdf. Accessed 21 December 2007.

\section{Biographical Notes}

THANDI NGCOBO is a senior lecturer in education management at the University of Western Cape. Her doctoral research was in the area of educational leadership and school culture and her current research interests include educational leadership and change and teacher education.

LEON PAUL TIKLY is Professor in Education in the Graduate School of Education, University of Bristol. His research interests include education management and policy in South Africa, the quality of education in low income countries and globalization and education in Africa. He directs a research programme consortium on implementing education quality in low income countries (EdQual).

Primary schools Secondary schools Combined schools Total 